\title{
CircRNA CDR I as/miR-7 signals promote tumor growth of osteosarcoma with a potential therapeutic and diagnostic value [Corrigendum]
}

\author{
Xu B, Yang T, Wang Z, Zhang Y, Liu S, Shen M. Cancer \\ Manag Res. 2018;10: 4871-4880.
}

On page 4879 there was an error in the Acknowledgments section. The correct information is listed as follows:

\section{Acknowledgments}

This work was supported by the National Natural Science Foundation of China (No. 81772383 to YZ), Key Discipline of Pudong New Area, Shanghai (PWZxk2017-18 to TYY) and Shanghai Municipal Commission of Health and Family Planning (No. 201540396 to ZW).

\section{Publish your work in this journal}

Cancer Management and Research is an international, peer-reviewed open access journal focusing on cancer research and the optimal use of preventative and integrated treatment interventions to achieve improved outcomes, enhanced survival and quality of life for the cancer patient. The manuscript management system is completely online and includes

\section{Dovepress}

a very quick and fair peer-review system, which is all easy to use. Visit http://www.dovepress.com/testimonials.php to read real quotes from published authors. 